\title{
Impacts of sulphur and nitrogen deposition in western Canada
}

\author{
Julian AHERNE** and D. Patrick SHAW ${ }^{1)}$ \\ Environmental and Resource Studies, Trent University, 1600 West Bank Drive, Peterborough, ON K9J 7B8, Canada \\ ${ }^{1)}$ Environment Canada, 201-401 Burrard Street, Vancouver, BC V6C 3S5, Canada \\ *corresponding author: e-mail: julian.aherne@ucd.ie
}

\begin{abstract}
The expansion of transportation sectors (road vehicles and marine vessels), industry (e.g., oil and gas) and urban centres in western Canada has triggered a growth in research, monitoring and modelling activities investigating the impacts of sulphur and nitrogen deposition on aquatic and terrestrial ecosystems. This special issue presents an overview of related research in British Columbia (Georgia Basin), Alberta (Athabasca Oil Sands Region), Saskatchewan and Manitoba. The research provides a valuable benchmark for future studies across the region and points the way forward for 'acid rain' policies in western Canada.
\end{abstract}

Key words: British Columbia, Alberta, Saskatchewan, Manitoba, critical load, acid rain

\section{INTRODUCTION}

Elevated emissions of anthropogenic sulphur (S) and nitrogen $(\mathrm{N})$ oxides have been a major environmental issue in eastern North America for decades owing to their impacts on precipitation chemistry (acid rain) and consequent negative effects on surface waters and forest soils. Recently there has been growing interest in western Canada (defined here as British Columbia, Alberta, Saskatchewan and Manitoba) where anthropogenic emissions of $\mathrm{S}$ and $\mathrm{N}$ oxides are expected to increase due to the expansion of the transportation sector (road vehicles and marine vessels), industry (e.g., Athabasca Oil Sands Region, Alberta) and urban centres (e.g., Georgia Basin, British Columbia). This is in contrast to eastern Canada where international agreements have resulted in significant reductions in the emissions of $\mathrm{S}$ and $\mathrm{N}$ oxides (Environment Canada 2004).

This interest has lead to several projects defining inputs, developing critical loads and monitoring ecosystem response to $\mathrm{S}$ and $\mathrm{N}$ in western Canada. Much of this research has focused on specific (localised) regions associated with the metal smelting industry, large population and industrial centres (e.g., Georgia Basin) and the oil and gas industry (e.g., Athabasca Oil Sands Region). During 28-29 April 2009, monitoring and research activities investigating the impacts of $\mathrm{S}$ and $\mathrm{N}$ deposition in western Canada were presented at a workshop in Banff, Alberta, co-sponsored by the Canadian Council of Ministers of the Environment, Cumulative Environmental Management Association, Environment Canada and the Wood Buffalo Environmental Association. Outputs from this workshop and from on-going research activities in western Canada are presented in this special issue.

\section{WORKSHOP}

The 'Western Canada Sulphur and Nitrogen Deposition Workshop' brought together researchers and stakeholders from across Canada, the United States and beyond to review and assess the state of the science on atmospheric ( $\mathrm{S}$ and $\mathrm{N}$ ) deposition and ecosystem impacts in western Canada, the implications to current policies, and to identify areas for future concentration in western Canada. Presentations from the workshop included in this special issue are: Curtis et al. (2010, this issue), Gibson et al. (2010a, this issue), Jeffries et al. (2010, this issue), Nasr et al. (2010, this issue), Raymond et al. (2010, this issue), Scott et al. (2010, this issue) and Wieder et al. (2010, this issue). The workshop summary recognized that scientific information and knowledge generated through research (including uncertainty where appropriate) must be translated into policy. Moreover, there is a degree of urgency for this policy development, due to the rate of environmental change currently occurring.

\section{SPECIAL ISSUE}

The papers in this special issue describe the influence of anthropogenic $\mathrm{S}$ and $\mathrm{N}$ emissions on air quality and subsequent impacts on aquatic and terrestrial ecosystems in British Columbia, Alberta, Saskatchewan and Manitoba (western Canada). The data provide valuable benchmarks for future studies across the region. Long-term trends in precipitation chemistry have responded to large-scale emissions reductions across North America with increased $\mathrm{pH}$ and decreased sulphate concentrations (Aherne et al. 2010, this issue; Feller 2010, this issue) consistent with observations in eastern Canada. Nitrogen deposition has also decreased 
(Feller et al. 2010, this issue) but the pattern was not consistent across the study region; moreover, atmospheric $\mathrm{N}$ concentrations may be a future concern for specific regions (e.g., northern Alberta, Bytnerowicz et al. 2010, this issue). Nonetheless these results are based on observations from limited stations across western Canada; optimistically lichen and moss bioindicators may provide a means to 'fill-in' the spatial gaps (Raymond et al. 2010, this issue).

The majority of the papers in the special issue focus on impacts to water quality and aquatic systems. Recent water quality surveys indicate that lakes in the Georgia Basin (Strang et al. 2010, this issue), northern Saskatchewan (Jeffries et al. 2010, this issue, Scott et al. 2010, this issue) and Manitoba (Jeffries et al. 2010, this issue) are very sensitive to acid deposition and have low critical loads of acidity (sulphate). Nonetheless, longterm trends in surface water chemistry show recovery (increased $\mathrm{pH}$ and decreased sulphate concentration). In addition to water quality, these surveys employed an isotope approach to estimate catchment-specific runoff volumes required to calculate critical loads (Gibson et al. 2010a \& b, this issue). The assessment of lakes in northern Alberta using macroinvertebrate, palaeolimnological and hydrogeochemical modelling approaches suggest that industrial activities associated with the oil sands presently have limited influence on lake acidification (Parsons et al. 2010a \& b, this issue; Curtis et al. 2010, this issue; Whitfield et al. 2010a \& b, this issue). Curtis et al. (2010, this issue) indicate that only one of their 12 study lakes showed strong evidence of acidification with a decline in diatom-inferred $\mathrm{pH}$; similarly, Whitfield et al. (2010a \& b, this issue) found limited potential for modelled acidification impacts (from primarily sulphate) at 50 study sites.

Several papers in the special issue also focused on impacts to terrestrial (vegetation and soil) systems. Wieder et al. (2010, this issue) found no impact of $\mathrm{N}$ and S deposition on the growth of Sphagnum fuscum in bogs in northern Alberta. Similarly, while Laxton et al. (2010, this issue) found a correlation between atmospheric $\mathrm{N}$ oxides and $\mathrm{N}$ concentrations in Pinus banksiana foliage in northern Alberta, there was no impact on $\mathrm{N}$ cycling. In contrast, papers focusing on the determination of critical loads of acidity ( $\mathrm{S}$ and $\mathrm{N}$ ) for forest soils predicted significant exceedance for the Georgia Basin (Mongeon et al. 2010, this issue; Nasr et al. 2010, this issue) and the Athabasca Oil Sands Region (Whitfield et al. 2010c, this issue) suggesting that acid-sensitive soils in both regions are at risk of acidifying. Although confined to 'hot spots' of sensitivity, the extent of exceedance in these regions is similar to eastern Canada.

The papers in the special help point the way forward for future 'acid rain' science and policy efforts in western Canada. Moreover they present the state of the science on atmospheric ( $\mathrm{S}$ and $\mathrm{N}$ ) deposition and ecosystem impacts highlighting the cross-fertilisation between research, environmental monitoring and modelling.

\section{SPECIAL ISSUE DEDICATION: BEVERLEY A. RAYMOND}

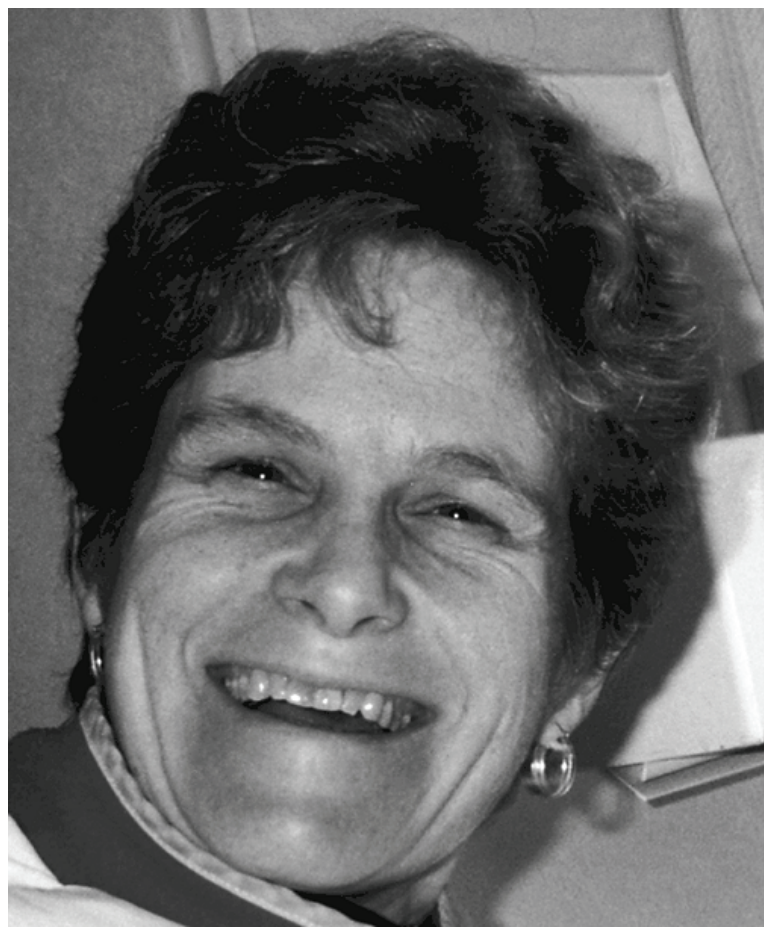

Beverley A. Raymond

Beverley Raymond started her career with Environment Canada in Vancouver, British Columbia working with water resource and water quality issues. Much of her effort was spent in assessing the effects of contaminants entering aquatic environments, developing water quality objectives and guidelines, and conducting field studies to support this work. With increasing concern about air quality in southwest British Columbia, Beverley seized on research opportunities to investigate the consequences of atmospheric deposition on both aquatic and terrestrial environments. This led to studies to understand the accumulation of atmospherically transported organics and metals in stream communities and to contaminant biomonitoring using both plant tissue chemistry and patterns in plant communities. Recognizing the need for useful management tools for atmospheric emissions, Beverley led a multi-partner research team tasked with developing regional critical loads for sulphur and nitrogen (Aherne et al. 2010, this issue; Gibson et al. 2010a, this issue; Mongeon et al. 2010, this issue; Nasr et al. 2010, this issue; Raymond et al. 2010, this issue; Strang et al. 2010, this issue). Her participation in this work was cut short by her untimely passing. This special issue in the Journal of Limnology is dedicated to the memory of Beverley A. Raymond. 


\section{ACKNOWLEDGEMENTS}

We would like to acknowledge the financial support of the Canadian Council of Ministers of the Environment (CCME), Cumulative Environmental Management Association (CEMA), Environment Canada and the Wood Buffalo Environmental Association (WBEA) in co-sponsoring the Western Canada Sulphur and Nitrogen Deposition workshop, and funding research and monitoring across western Canada. Further, this research was undertaken, in part, thanks to funding from the Canada Research Chairs Program and a Natural Sciences and Engineering Research Council of Canada Discovery grant. We sincerely thank the Journal of Limnology and Dr. Gianluigi Giussani for accomodating and supporting this special issue. Finally, we gratefully acknowledge and appreciate the time and effort of the reviewers across Europe and North America who have helped to improve the quality of this special issue. Thank you.

\section{REFERENCES}

Aherne, J., A. Mongeon \& S.A. Watmough. 2010. Temporal and spatial trends in precipitation chemistry in the Georgia Basin, British Columbia. J. Limnol., 69(Suppl. 1): 4-10. DOI: 10.3274/JL10-69-S1-02.

Bytnerowicz, A., W. Fraczek, S. Schilling \& D. Alexander. 2010. Spatial and temporal distribution of ambient nitric acid and ammonia in the Athabasca Oil Sands Region, Alberta. J. Limnol., 69(Suppl. 1): 11-21. DOI: 10.3274/ JL10-69-S1-03.

Curtis, C., R. Flower, N. Rose, J. Shilland, G. Simpson, S. Turner, H. Yang \& S. Pla. 2010. Palaeolimnological assessment of lake acidification and environmental change in the Athabasca Oil Sands Region, Alberta. J. Limnol., 69(Suppl. 1): 92-104. DOI: 10.3274/JL10-69-S1-10.

Environment Canada. 2004. Canadian acid deposition science assessment. Meteorological Service of Canada, Ottawa, Ontario: $440 \mathrm{pp}$.

Feller, M. 2010. Trends in precipitation and streamwater chemistry in East Creek watershed in southwestern British Columbia, 1971-2008. J. Limnol., 69(Suppl. 1): 77-91. DOI: 10.3274/JL10-69-S1-09

Gibson, J.J., S.J. Birks, D.S. Jeffries, S. Kumar, K.A. Scott, J. Aherne \& D.P. Shaw. 2010a. Site-specific estimates of water yield applied in regional acid sensitivity surveys across western Canada. J. Limnol., 69(Suppl. 1): 67-76. DOI: 10.3274/JL10-69-S1-08

Gibson, J.J., S.J. Birks, S. Kumar, P. McEachern \& R. Hazewinkel. 2010b. Inter-annual variations in water yield to lakes in northeastern Alberta: implications for estimating critical loads of acidity. J. Limnol., 69(Suppl. 1): 126-134. DOI: $10.3274 / J L 10-69-S 1-13$.

Jeffries, D.S., R.G. Semkin, J.J. Gibson \& I. Wong. 2010. Recently surveyed lakes in northern Manitoba and
Saskatchewan, Canada: characteristics and critical loads of acidity. J. Limnol., 69(Suppl. 1): 45-55. DOI: 10.3274/ JL10-69-S1-06.

Laxton, D., S.A. Watmough, J. Aherne \& J. Straker. 2010. An assessment of nitrogen saturation in Pinus banksiana plots in the Athabasca Oil Sands Region, Alberta. J. Limnol., 69(Suppl. 1): 171-180. DOI: 10.3274/JL10-69-S1-17.

Mongeon, A., J. Aherne \& S.A. Watmough. 2010. Steadystate critical loads of acidity for forest soils in the Georgia Basin, British Columbia. J. Limnol., 69(Suppl. 1): 193200. DOI: 10.3274/JL10-69-S1-19.

Nasr, M., M. Castonguay, J. Ogilve, B.A. Raymond \& P.A. Arp. 2010. Modelling and mapping critical loads and exceedances for the Georgia Basin, British Columbia, using a zero base-cation depletion criterion. J. Limnol., 69(Suppl. 1): 181-192. DOI: 10.3274/JL10-69-S1-18.

Parsons, B.G., S.A. Watmough, P.J. Dillon \& K.M. Somers. 2010a. A bioassessment of lakes in the Athabasca Oil Sands Region, Alberta, using benthic macroinvertebrates. J. Limnol., 69(Suppl. 1): 105-117. DOI: 10.3274/JL10-69S1-11.

Parsons, B.G., S.A., Watmough, P.J. Dillon \& K.M. Somers. 2010b. Relationships between lake water chemistry and benthic macroinvertebrates in the Athabasca Oil Sands Region, Alberta. J. Limnol., 69(Suppl. 1): 118-125. DOI: 10.3274/JL10-69-S1-12

Raymond, B.A., T. Bassingthwaighte \& D.P. Shaw. 2010. Measuring nitrogen and sulphur deposition in the Georgia Basin, British Columbia, using lichens and moss. $J$. Limnol., 69(Suppl. 1): 22-32. DOI: 10.3274/JL10-69-S1-04.

Scott, K.A., B, Wissel, J.J. Gibson \& S.J. Birks. 2010. Chemical characteristics and acid sensitivity of boreal headwater lakes in northwest Saskatchewan. J. Limnol., 69(Suppl. 1): 33-44. DOI: 10.3274/JL10-69-S1-05.

Strang, D., J. Aherne \& D.P. Shaw. 2010. The hydrochemistry of high-elevation lakes in the Georgia Basin, British Columbia. J. Limnol., 69(Suppl. 1): 56-66. DOI: 10.3274/ JL10-69-S1-07.

Whitfield, C.J., J. Aherne, B.J. Cosby \& S.A. Watmough. 2010a. Modelling boreal lake catchment response to anthropogenic acid deposition. J. Limnol., 69(Suppl. 1): 135146. DOI: 10.3274/JL10-69-S1-14.

Whitfield, C.J., J. Aherne, B.J. Cosby \& S.A. Watmough. 2010b. Modelling catchment response to acid deposition: a regional dual application of the MAGIC model to soils and lakes in the Athabasca Oil Sands Region, Alberta. $J$. Limnol., 69(Suppl. 1): 147-160. DOI: 10.3274/JL10-69S1-15.

Whitfield, C.J., J. Aherne, S.A. Watmough \& M. McDonald. 2010c. Estimating the sensitivity of forest soils to acid deposition in the Athabasca Oil Sands Region, Alberta. $J$. Limnol., 69(Suppl. 1): 201-208. DOI: 10.3274/JL10-69S1-20.

Wieder, R.K., D.H. Vitt, M. Burke-Scoll, K.D. Scott, M. House \& M.A. Vile. 2010. Nitrogen and sulphur deposition and the growth of Sphagnum fuscum in bogs of the Athabasca Oil Sands Region, Alberta. J. Limnol., 69(Suppl. 1): 161-170. DOI: 10.3274/JL10-69-S1-16. 